\title{
Bacterial Surfaces as Revealed by the High Resolution Scanning Electron Microscope
}

\author{
By KAZUNOBU AMAKO AND AKIKO UMEDA \\ Department of Microbiology, School of Medicine, Fukuoka University, \\ Fukuoka 814, Japan
}

(Received 8 July 1976; revised I September 1976)

INTRODUCTION

It has been demonstrated that the 'field-emission source' scanning electron microscope can resolve single virus particles on cell surfaces (Amako, 1975; Amako et al., 1974). At this high resolution, it is possible to examine the three-dimensional fine structure of bacterial surfaces not otherwise revealed by the conventional scanning electron microscope.

In this communication, we describe the surface structures of some Gram-negative and Gram-positive bacteria revealed using this high resolution scanning electron microscopic technique.

\section{METHODS}

Organism. The bacterial strains used were Escherichia coli strain B, Bacillus subtilis strain

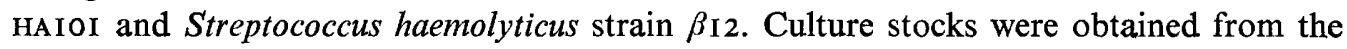
Department of Bacteriology, School of Medicine, Kyushu University, Japan. Escherichia coli and $B$. subtilis were grown in nutrient broth; $S$. haemolyticus was grown in heart infusion broth (Merck).

Preparation of bacteria for scanning electron microscopy. Bacteria were grown in aerated liquid media to the exponential phase and harvested by centrifuging at $1000 \mathrm{~g}$ for $30 \mathrm{~min}$. The bacterial pellet was fixed with $\mathrm{I} \%(\mathrm{v} / \mathrm{v})$ glutaraldehyde for $30 \mathrm{~min}$ then with $\mathrm{I} \%(\mathrm{w} / \mathrm{v})$ osmium tetroxide for $\mathrm{I} 2$ to $20 \mathrm{~h}$, both treatments being done in a refrigerator. Fixatives were prepared in $0.15 \mathrm{M}$-sodium cacodylate buffer, $\mathrm{pH} 7.0$. The fixed pellet was dehydrated in a graded ethanol series from $50 \%$ to $100 \%$, followed by amyl acetate, then dried by the 'critical point' method. The dried pellet was broken into small fragments with the tip of forceps and pressed on to an aluminium block. The preparation was then coated with gold/palladium (60:40). The thickness of the metal coating was controlled so that it did not exceed Io nm, using a deposit thickness monitor (DTM-2; Sloan Instrument Corp., Santa Barbara, California, U.S.A.). The Hitachi HFS-2 field emission source electron microscope was operated at $25 \mathrm{kV}$.

\section{RESULTS AND DISCUSSION}

Scanning electron micrographs of $E$. coli showed a characteristic wavy surface (Fig. I $a$ ). The waviness was apparently not due to the method of fixation since this characteristic was observed in all Gram-negative bacteria examined, including Vibrio cholerae and Pseudomonas aeruginosa, but not in Gram-positive bacteria. The phenomenon may reflect the chemical differences of the outermost surfaces of Gram-positive and Gram-negative bacteria (Nikaido, 1973). Bayer \& Remsen (1970) have stated that waviness of bacterial surfaces was' not detected in freeze-fractured specimens, but was frequently observed on 

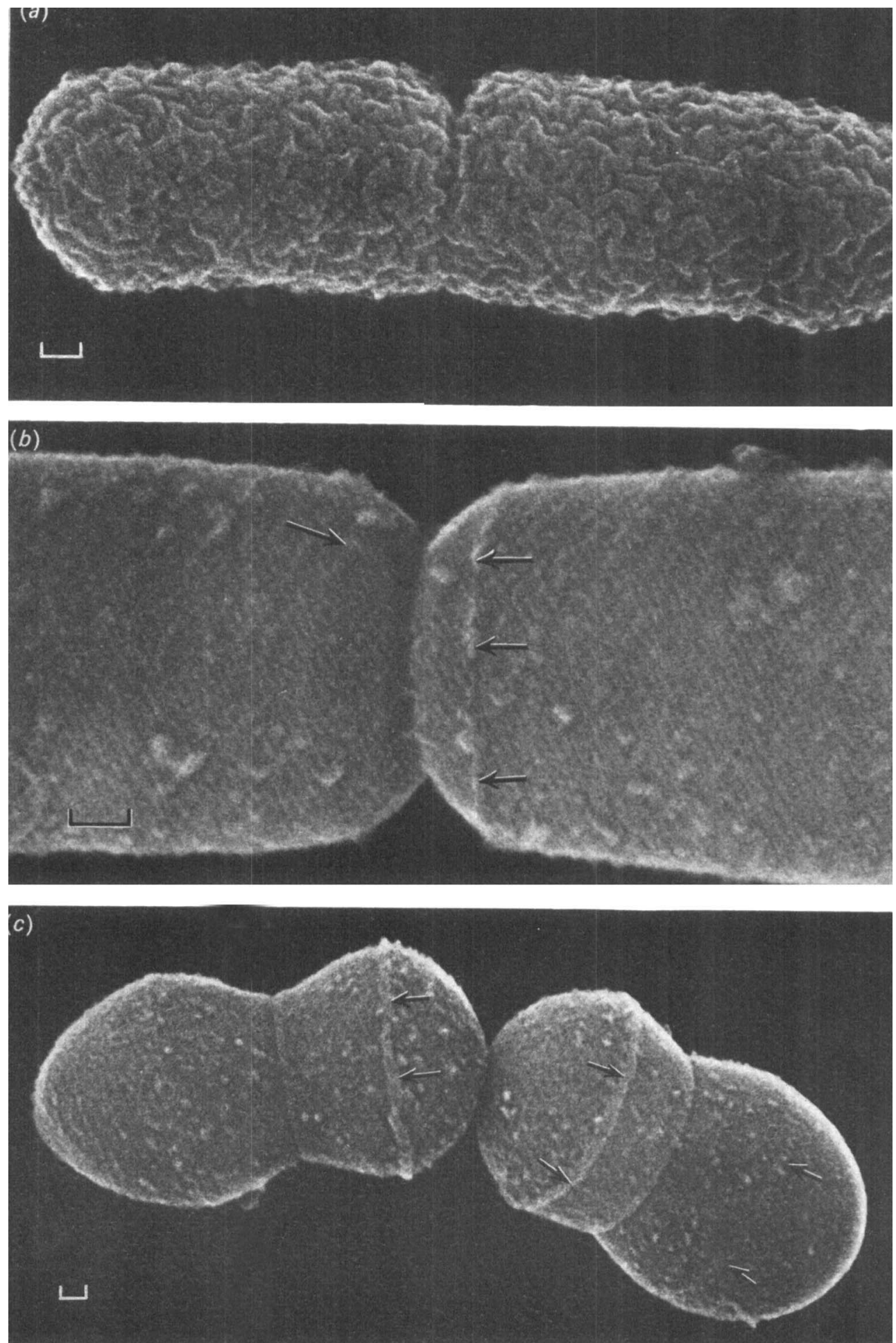

Fig. I. Scanning electron micrographs of some Gram-negative and Gram-positive bacteria: (a) E. coli strain B; (b) B. subtilis strain HAIOI; (c) S. haemolyticus strain $\beta_{12}$. Arrows indicate the ridges. Bar markers represent $100 \mathrm{~nm}$. 
negatively stained or thin-sectioned profiles which had been dried or dehydrated during their processing. This implied that the wavy structure of Gram-negative bacteria could be an artefact induced during the dehydration process.

The surfaces of the Gram-positive bacteria, B. subtilis (Fig. I b) and S. haemolyticus (Fig. I $c$ ), appeared to be relatively smooth compared with the surface of $E$. coli. Characteristic features of Gram-positive bacteria included the presence of ridges (arrowed in Fig. $\mathrm{I} b, c$ ), which extended around the circumference of bacteria and divided the cell surface into two or more areas. Since these ridges were usually found adjacent to the dividing plane of bacteria, the areas separated by a ridge might represent 'old' and 'new' surfaces exposed by separation. No such structures were observed in Gram-negative bacteria. This suggested that wall synthesis during cell division was different in the two types of bacteria, as observed by Cole (1965) in the light microscope.

The ridges observed on $S$. haemolyticus (Fig. I $c$ ) might be similar to the 'wall bands' detected by Higgins \& Schockman (1970) on examination of thin-sections of Streptococcus faecalis.

Curiously, no flagella were detected on $E$. coli and $B$. subtilis which are known to be flagellated strains. This was undoubtedly due to an artefact induced during the fixation and dehydration of these strains (M. Matsuguchi, personal communication).

The present observations indicate the usefulness of the high resolution scanning electron microscope in microbiological investigation, especially in studies on cell division or wall synthesis.

We are grateful to Miss Keiko Shigematsu for her help in preparing this manuscript.

\section{REFERENCES}

Aмако, K. (1975). Scanning electron microscopy of the releasing process of influenza virus. Japanese Journal of Microbiology 19, 452-455.

Amako, K., TakeYa, K., Nagatani, T. \& SAIto, M. (1974). Bacteriophage and bacteriocin as revealed by field emission source scanning electron microscope. Journal of Electron Microscopy 23, 301-302.

BAYER, M. E. \& REMSEN, C. C. (I970). Structure of Escherichia coli after freeze-etching. Journal of Bacteriology ror, 304-3I3.

Cole, R. M. (1965). Symposium on the fine structure and replication of bacteria and their parts. III. Bacterial cell-wall replication followed by immunofluorescence. Bacteriological Reviews 29, 326-344.

Higgins, M. L. \& Schockman, G. D. (1970). Model for cell wall growth of Streptococcus faecalis. Journal of Bacteriology Ior, 643-648.

NrkaIDO, H. (1973). Biosynthesis and assembly of lipopolysaccharide and outer membrane layer of Gramnegative cell wall. In Microbiology series, vol. I: Bacterial Membranes and Walls., pp. I3I-208. Edited by L. Leive. New York: Marcel Dekker. 